\title{
Pilot-Scale Bio-Augmented Aerobic Composting of Excavated Foot-And-Mouth Disease Carcasses
}

\author{
Seonghoon Kim ${ }^{1}$, Hyeji Kwon ${ }^{1}$, Suchan Park ${ }^{1}$, Haeseong Jeon ${ }^{2}$, Joon-kyu Park ${ }^{2}$ and \\ Joonhong Park ${ }^{1, *}$ \\ 1 Department of Civil and Environmental Engineering, College of Engineering, Yonsei University, Seoul 03722, \\ Korea; ebtl_sh@yonsei.ac.kr (S.K.); ghjghj86@probioticslab.com (H.K.); psch0906@naver.com (S.P.) \\ 2 Dasan Consultants R\&D Center, Seoul 05800, Korea; tour2139@naver.com (H.J.); \\ parkjk@dasan93.co.kr (J.-k.P.) \\ * Correspondence: jpark@yonsei.ac.kr; Tel.: +82-2-312-5798
}

Academic Editors: Geonha Kim, Daniel C.W. Tsang, Zeng-Yei Hseu, Chaeyoung Lee, Meththika Vithanage and Yong Sik Ok

Received: 30 December 2016; Accepted: 13 March 2017; Published: 17 March 2017

\begin{abstract}
In the present work, we tested the validity of using novel, bio-augmented, aerobic composting with carcass-degrading microorganisms for the ex situ stabilization of carcasses at pilot scale with previously poorly decomposed carcasses excavated from a 3-year old burial site. The significantly decreased chemical oxygen demand (COD, 160,000 mg/kg to 40,000 mg/kg) and inorganic nitrogen species (total nitrogen, $5000 \mathrm{mg} / \mathrm{kg}$ to $2000 \mathrm{mg} / \mathrm{kg}$ ) indicated effective bio-stabilization of carcasses by bio-augmented composting. The subsequent germination assays and the quantitative characterization of potentially pathogenic bacteria using NGS (next-generation sequencing) showed that the burial-composting sequential system with the carcass-degrading microorganisms and mechanical agitation successfully reduced plant toxicity as well as microbial risk to human health, suggesting that the composting by-product is suitable for farming or/and landfill use(s).
\end{abstract}

Keywords: bacterial pathogens; bio-augmented aerobic composting; carcass-degrading microorganisms; early stabilization; plant toxicity

\section{Introduction}

With a global production of approximately $1.5 \times 10^{9}$ cattle and $9.8 \times 10^{8}$ pigs [1], the risk of infection by livestock epidemics, such as foot-and-mouth disease (FMD), tends to increase, threatening national food safety and economy. FMD, a highly transmissible viral disease of cloven-hoofed animals, is considered as one of the most serious and economically significant diseases of livestock animals [2]. FMD outbreaks have been reported worldwide, including in the United Kingdom, Taiwan, Japan, China, Korea, and so on. Carcasses that are infected or suspected of being infected by livestock infectious diseases have been treated by a wide range of treatment methods including burial, burning, incineration, rendering, and composting, and the choice of carcass treatment method(s) varies depending upon the individual country's policy and regulation [3-5].

Burial is a traditional way to burrow carcasses in graves, trenches or landfills. Burial has the advantage of minimizing the spread of disease and of treating a large amount of carcasses in short times. Its main drawbacks are potential leachate release from decomposed carcasses to the subsurface environment, which can lead to secondary contaminations of the surface water environment and farming land [5-7]. Onsite-burning and incineration are regarded as effective methods in destroying infectious agents. However, the uses of onsite burning and incineration have been reduced or often banned due to public concerns about the production of dioxin and odor 
from incomplete combustion [8,9]. In the case of rendering, in which carcasses are crushed into fat, proteinaceous material and water [10], it requires high energy for treatment and high initial facility costs. Onsite-burning, incineration, and rendering are not good for large scale treatment of infected carcasses. In addition, their products are subject to disposal in landfills designed for that specific purpose or subject to incineration [11]. To circumvent the problems from the above-mentioned methods, composting is often regarded as an alternative, not only because subsurface environmental contamination can be avoided by its leachate control but also because large amounts of carcasses can be treated $[12,13]$. In addition, auto-thermal reaction during aerobic composting causes the temperature to increase up to $70{ }^{\circ} \mathrm{C}$, sterilizing significant amounts of pathogenic microorganisms in products from composting $[12,13]$.

In Korea, large scale FMD outbreaks occurred between 2010 and 2011, and approximately 9.8 million domestic animals were disposed of in approximately 4800 burials [14]. From some of the burials, groundwater and river were contaminated with leachate. In addition, buried carcasses were often found to be undecomposed even after the legal burial period (3 years) in Korea [14,15]. Because the FMD virus was inactivated after the 3-year burial period, the Korean government has considered the novel approach of moving the undecomposed carcasses from the burial sites into other sites for further treatment in order to reuse the land areas used for the burial purposes. To evaluate the feasibility of this novel approach, we have conducted pilot-scale composting (Icheon, Gyeonggi Province, Korea) to biologically stabilize the undecomposed carcasses from a 3-year old burial site [15]. To enhance the bio-stabilization, a carcass-degrading bacterium (Corynebacterium glutamicum) and other materials stimulating carcass degradation activities were aerobically mixed with previously buried carcasses using a rotary agitation system. To the best of our knowledge, this was the first trial to evaluate the feasibility of bio-augmented aerobic composting of excavated carcasses from a burial.

In terms of feasible bio-stabilization of excavated carcasses, groundwater protection and plant toxicity are the main considerations. Because dissolved organic matter and nitrogen species such as ammonia are contaminants to groundwater, it is necessary to examine whether bio-augmented composting can effectively eliminate such organic matter and nitrogen contaminants from previously buried carcasses. In addition, if the final product of bio-augmented composting of carcasses is applied as soil, no plant toxicity should be guaranteed. However, little is known about the effects of bio-augmented composting on the reduction of organic matter and nitrogen contaminants and potential plant toxicity.

In addition to the groundwater protection and plant toxicity, bacterial pathogenicity to human beings is an important factor in evaluating the feasibility of composting of carcasses. However, the methodology of assessing bacterial pathogenicity in biologically stabilized carcasses still remains poorly established. Currently, cultivation-based detection of bacterial pathogen indicators is used in assessing the microbial risk of buried carcasses $[16,17]$. However, the current cultivation-dependent detection may not be suitable for evaluating microbial risk in composed carcasses because of the fact that only $5 \%-10 \%$ of the microbes in environmental samples are detectable by cultivation $[16,17]$. To circumvent the methodological limitation, NGS (next generation sequencing) methods sequencing $16 \mathrm{~S}$ rRNA gene segments in microbial community DNA have been widely used in the area of microbial ecology [18]. According to other recent studies using pyrosequencing (one of the NGS methods) targeting the bacterial 16S rRNA gene, the detected potential pathogenic bacteria were quite different from the cultivable pathogen indicators currently used in evaluating microbial risk in buried carcasses [16,17]. This led us to the need to investigate bacterial community characteristics and dominant potential bacterial pathogens in composted carcasses using NGS.

In this work, we attempted to evaluate the feasibility of bio-augmented aerobic composting of excavated carcasses from a 3-year old burial. For this, the reduction of organic matter and nitrogen contaminants was monitored in pilot-scale bio-augmented aerobic composting, and potential plant toxicity was tested in the final product from bio-augmented aerobic composting. Furthermore, MiSeq (one of the NGS methods) targeting the bacterial 16S rRNA gene was used to investigate 
the characteristics of bacterial communities and the quantitative information of potentially pathogenic bacteria in the composted carcasses.

\section{Materials and Methods}

\subsection{Environmental Management Research Facility for Carcasses Burial at Pilot Scale}

An environmental management research facility for carcass burial was constructed in 2015 in Icheon, Gyeonggi Province, Korea by SAFE research center for environmental management of carcasses burial sites (Figure 1). It was equipped with a barrier-disinfection facility; fence and dustproof facility; an electricity and water facility; a carcass crushing facility; a carcass-soil separation facility; a carcass storage facility; a carcass bio-degradation evaluation facility; a carcass decommissioning device; and a soil purification facility.

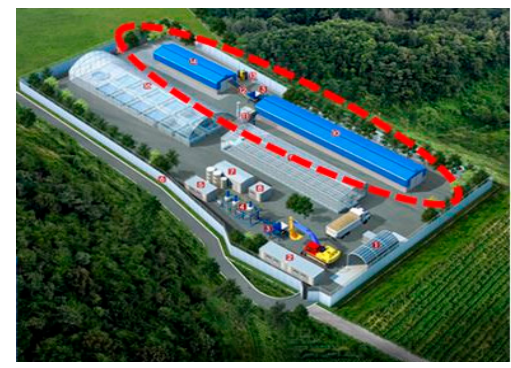

(a)

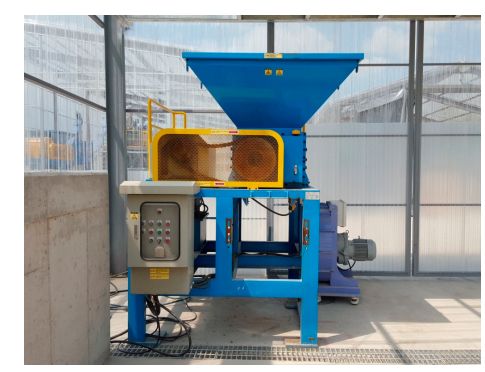

(b)

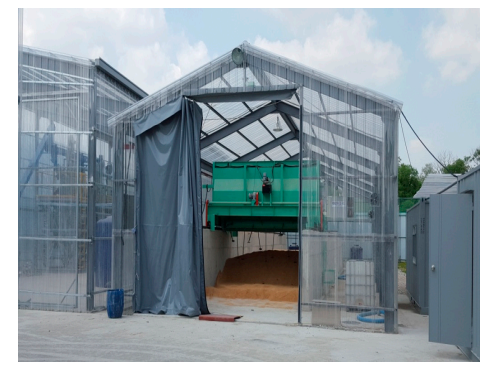

(c)

Figure 1. Front view of the research facilities and two main facilities of bio-reduction: (a) front view of the research facility (the bio-crusher and bio-agitator are located in the red circle); (b) bio-crusher; (c) bio-agitator and bio-degradation evaluation facility.

The pretreatment facility has a width of $7.0 \mathrm{~m}$, a length of $32.0 \mathrm{~m}$, a wall height of $1.5 \mathrm{~m}$, and has a volume of $336.0 \mathrm{~m}^{3}$ for storing carcasses excavated from a burial site. The carcass crusher should not be clogged during the crushing process, and the primary goal is to crush carcasses to a maximum size of $10 \mathrm{~cm}$ to reduce the load during the rotary rotation of the agitator. The manufacturing goal was to make it easy to break down components of a certain strength, such as bones and horns, and tough components, such as leather and guts. Considering these difficulties, the bio-crusher was designed with a $20 \mathrm{HP}$ (horse-power) crushing motor and could crush 5 tons of carcasses per hour. The bio-degradation evaluation facility with the bio-agitator has a width of $4.75 \mathrm{~m}$, a length of $25.0 \mathrm{~m}$, a wall height of $1.8 \mathrm{~m}$, a total area of $120.0 \mathrm{~m}^{2}$, and an appropriate stirring volume of $180.0 \mathrm{~m}^{3}$. The leachate from carcasses is collected in a reservoir by a discharge frame (an air passage) in the bottom. The rotary bio-agitator can transport and agitate carcasses, control the stirring depth, constantly maintain the rotational speed, and be operated in the forward and reverse directions.

\subsection{Information about the Carcass Burial Site}

The burial site used in this study was constructed in Gyeonggi Province in January 2011, and 186 cattle infected with FMD were urgently buried. The carcasses from the site were transported and stabilized at the pilot-scale environmental management research facility for carcass burial. Table 1 shows the details of the site. 
Table 1. Description of the carcass burial site.

\begin{tabular}{cc}
\hline Parameter & Description \\
\hline Location & Gyeonggi Province \\
Type of buried animal & Cattle \\
Number of buried animal & 186 \\
Dimension of disposal site & $5 \mathrm{~m} \times 5 \mathrm{~m} \times 20 \mathrm{~m}$ \\
Date of burial & 21 January 2011 \\
\hline
\end{tabular}

\subsection{Process and Operating Conditions}

The carcass treatment processes are shown in Figure 2. Incompletely decomposed carcasses were excavated from the targeted burial site and transported and deposited at the pretreatment facility. The pretreatment facility physically obstructed the transportation of odor and airborne contaminants to the outside during the storage period. The stored carcasses were shredded by the bio-crusher and transported to the bio-degradation evaluation facility. In the bio-degradation evaluation facility, a bio-agitator was used as a large livestock stirrer to maintain aerobic conditions in order to enhance the stabilization of the carcasses.

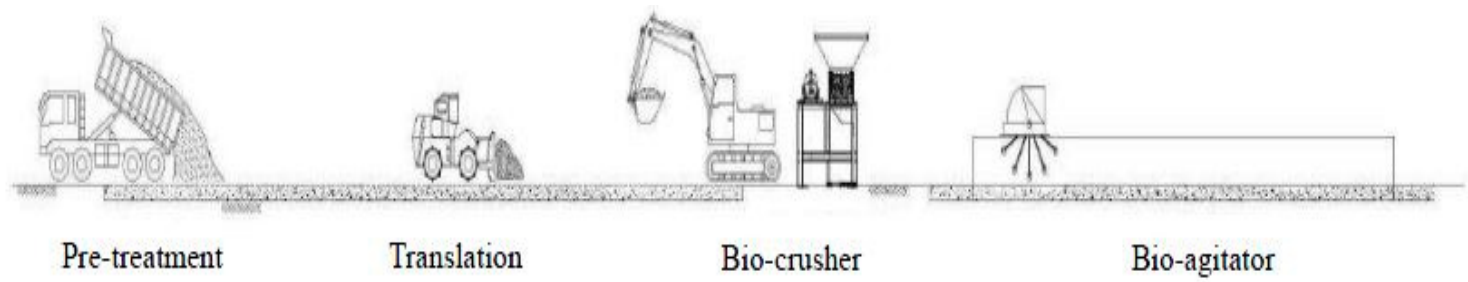

Figure 2. The process flow chart of carcass bio-reduction.

The operating conditions of the bio-degradation evaluation facility are shown in Table 2 .

Table 2. Conditions of the biodegradation evaluation facility.

\begin{tabular}{cc}
\hline Parameter & Conditions \\
\hline Bio-agitator operation frequency & 3 times a week \\
Temperature & $50-55{ }^{\circ} \mathrm{C}$ \\
Moisture content & $\geq 15 \%-20 \%$ \\
Bulking material & Rice hulls $1: 0.7-1$ (Volume ratio) \\
Microorganism & Corynebacterium glutamicum 280 L into 25 tons of \\
& carcasses (once a week) \\
\hline
\end{tabular}

Water was replenished by a water spraying facility, and the moisture content of the carcass pile was maintained at $15 \%-20 \%$ or more before spraying water to reach the appropriate moisture content $(40 \%)$. Decomposition was promoted by using a water spraying device to maintain the appropriate moisture content of the carcasses, and the bio-degradation performance of the aerobic microorganisms was maximized by the bio-agitator. When composting livestock manure, oxygen deficiency commonly occurs due to compression by self-weight. To prevent this condition and to optimize the activity of the microorganisms, an adequate level of bulking material is needed [19]. The bulking material was stirred to maintain the proper moisture content and air permeability. In this study, rice hulls were used as the bulking material. Corynebacterium glutamicum was used as the carcass-degrading microorganism. This microorganism can fertilize soil by producing useful amino acids from the treatment of organic matter, and it is known to be effective for degrading livestock carcasses [15]. The microorganism was cultivated with molasses $(1 \%)$ onsite to increase the efficiency, and it was added once a week at a concentration of $3.0 \times 10^{7}-1.0 \times 10^{8}$ gene copies $/ \mathrm{mL}$ to accelerate carcass degradation. The concentration of residual 
molasses filtered through $0.2 \mu \mathrm{m}$ membrane filters (Whatman ${ }^{\mathrm{TM}}$, Buckinghamshire, UK) after culturing was measured under $1000 \mathrm{mg}$-COD/L-media (approximately $11.2 \mathrm{mg}$-COD/kg-carcass) and it was considered to affect to the carcass degradation insignificantly.

\subsection{Sampling Carcasses in the Bio-Degradation Evaluation Facility}

After rotating carcasses with the bio-agitator in the bio-degradation evaluation facility, more than three carcass samples were collected from each area by dividing the carcass pile into three sections at least once a week. Fresh samples were stored in closed plastic bags in a refrigerator at $4{ }^{\circ} \mathrm{C}$ during the experiments. Before analysis, samples were pulverized using a mortar and pestle.

\subsection{Total Solids (TS) and Volatile Solids (VS)}

The TS and VS of the carcass samples were measured using the United States Environmental Protection Agency (EPA) method 1684. Evaporating dishes were heated at $550{ }^{\circ} \mathrm{C}$ for $1 \mathrm{~h}$ in an oven, cooled, dried in a desiccator and weighed $\left(\mathrm{W}_{\text {dish }}\right)$. Samples $(25-50 \mathrm{~g})$ pulverized by hand were prepared in triplicate and were placed into the dishes and weighed $\left(\mathrm{W}_{\text {sample }}\right)$. The dishes were dried at $103^{\circ} \mathrm{C}$ to $105^{\circ} \mathrm{C}$ for a minimum of $12 \mathrm{~h}$ and were then cooled to the balance temperature in a desiccator and weighed $\left(\mathrm{W}_{\text {total }}\right)$. The evaporating dishes containing dried residues were heated at $550{ }^{\circ} \mathrm{C}$ for $2 \mathrm{~h}$, and the residue was cooled in a desiccator and weighed $\left(\mathrm{W}_{\text {volatile }}\right)$. All measurements were performed in triplicate. The TS and VS were calculated using the following equations:

$$
\begin{gathered}
\left.\% \text { Total solids }=\left(\mathrm{W}_{\text {total }}-\mathrm{W}_{\text {dish }}\right) /\left(\mathrm{W}_{\text {sample }}-\mathrm{W}_{\text {dish }}\right) \times 100\right) \\
\% \text { Volatile solids }=\left(\mathrm{W}_{\text {total }}-\mathrm{W}_{\text {volatile }}\right) /\left(\mathrm{W}_{\text {total }}-\mathrm{W}_{\text {dish }}\right) \times 100
\end{gathered}
$$

\subsection{Chemical Oxygen Demand (COD) and Inorganic Nitrogen Measurment}

Distilled water $(100 \mathrm{~mL})$ was added to tubes with an amount of $10 \mathrm{~g}$ from the sample dried at $60^{\circ} \mathrm{C}$ during $24 \mathrm{~h}$. The tubes were shaken for $2 \mathrm{~h}$ and allowed to stand for a further $30 \mathrm{~min}$ to equilibrate and the supernatant was filtered through $0.2 \mu \mathrm{m}$ membrane filters (Whatman ${ }^{\mathrm{TM}}$, Buckinghamshire, UK). The soluble COD of the carcass was measured using a spectrophotometer (DR4000, HACH, Loveland, $\mathrm{CO}, \mathrm{USA}$ ) with $\mathrm{HACH}$ COD digestion reagent ( $\mathrm{HACH}$, Loveland, $\mathrm{CO}$, USA). Inorganic nitrogen $\left(\mathrm{NO}_{2}{ }^{-}, \mathrm{NO}_{3}{ }^{-}\right.$and $\left.\mathrm{NH}_{4}{ }^{+}-\mathrm{N}\right)$ was measured using a previously described method and $\mathrm{HACH}$ $\mathrm{NO}_{2}{ }^{-}, \mathrm{NO}_{3}{ }^{-}$and $\mathrm{NH}_{3}$ digestion reagents (HACH, Loveland, $\left.\mathrm{CO}, \mathrm{USA}\right)$. All measurements were performed in triplicate, and t-tests were used to test for significant differences.

\subsection{Germination Test and Organic Matter Measurement}

A germination test was performed using white radish seeds. A $10 \mathrm{~g}$ sample with a moisture content of $50 \%$ was added to $100 \mathrm{~mL}$ of distilled water and extracted using a reflux condenser for $2 \mathrm{~h}$. The extract was filtered through a No. 2 filter, and $5 \mathrm{~mL}$ of the filtrate was added to an $85 \mathrm{~mm}$ diameter petri dish with white radish seeds. The control was performed with $5 \mathrm{~mL}$ of distilled water. The number of seeds per petri dish was 30. After 5 days, the germination rate and root length of seedlings were measured. The germination index was calculated using the following equations:

$$
\begin{aligned}
\mathrm{GR}= & (\text { germination rate of the sample } / \text { germination rate of the control }) \times 100 \\
& \mathrm{RE}=(\text { root length of the sample/root length of the control }) \times 100
\end{aligned}
$$$$
\text { Germination index }=(\mathrm{GR} \times \mathrm{RE}) / 100
$$

This test was performed by the Foundation of Agriculture Technology Commercialization \& Transfer (FACT) in Korea. 
The organic matter in the carcass samples was measured by the Tyurin method. The samples were oxidized by $\mathrm{K}_{2} \mathrm{Cr}_{2} \mathrm{O}_{7}$ under strongly acidic conditions with concentrated sulfuric acid, and the carbon content was measured based on the amount of $\mathrm{K}_{2} \mathrm{Cr}_{2} \mathrm{O}_{7}$ consumed for oxidation. The amount of organic matter was determined by multiplying the carbon content by 1.724 (the ratio of the carbon content was $57 \%$ during soil erosion). The measurement was performed by FACT in Korea.

\subsection{DNA Extraction, Quantitative Real-Time PCR Analysis, PCR Amplification and MiSeq Sequencing}

Total genomic DNA was extracted from the carcasses at the bio-degradation evaluation facility using a Power Soil DNA Extraction Kit (MoBio, Carlsbad, CA, USA) according to the manufacturer's protocol. The extracted DNA was stored at $-20^{\circ} \mathrm{C}$ prior to the subsequent analysis.

Real-time PCR amplification reactions of the 16S rRNA gene were performed using a BIORAD iQ5 (Bio-Rad, Hercules, CA, USA) to quantify the bacteria. The reaction mixture had a total volume of $25 \mu \mathrm{L}: 12.5 \mu \mathrm{L}$ of iQ5 SYBR Green Supermix (Bio-Rad, Hercules, CA, USA), $10 \mathrm{ng}$ of total DNA, $1 \mu \mathrm{L}$ of $10 \mathrm{mM} 16 \mathrm{~S}$ rRNA primer $[20,21]$ and RNase-free water as the remaining volume. To amplify the $16 \mathrm{~S}$ rRNA gene from the extracted DNA, 16S amplicon PCR forward and reverse primers targeting the V3-V4 region of the 16S rRNA gene were used [22].

The PCR reaction mixtures contained $2.5 \mu \mathrm{L}$ of gDNA from the samples, $5 \mu \mathrm{L}$ of each primer $(1 \mu \mathrm{M})$ and $12.5 \mu \mathrm{L}$ of $2 \times$ KAPA Hi Fi HotStart Ready Mix (Invitrogen, Carlsbad, CA, USA). Amplification was performed using a C1000TM thermal cycler (Bio-Rad, Hercules, CA, USA) with the following conditions: an initial denaturation at $94{ }^{\circ} \mathrm{C}$ for $1 \mathrm{~min} ; 30$ cycles at $94{ }^{\circ} \mathrm{C}$ for $1 \mathrm{~min}, 50{ }^{\circ} \mathrm{C}$ for $1 \mathrm{~min}$, and $72{ }^{\circ} \mathrm{C}$ for $2 \mathrm{~min}$; and a final extension at $72{ }^{\circ} \mathrm{C}$ for $5 \mathrm{~min}$. Gel electrophoresis was performed to confirm the PCR amplification. Amplicon sequencing was performed by Macrogen (Seoul, Korea) using an Illumina MiSeq platform. The Shannon index was used to measure the diversity of the microorganisms of the carcasses. The diversity index was calculated using the following equation [23]:

$$
\text { Shannon index }=-\sum_{i} p_{i} \ln p_{i}\left(p_{i}=\text { proportion of individuals in species }\right)
$$

\subsection{Potentially Pathogenic Bacteria Identification}

To identify potential pathogens, the $16 \mathrm{~S}$ rRNA gene sequences (from the previously mentioned steps) were matched with the US EPA database of potentially pathogenic bacteria using BLAST (blastn, identity $\geq 97 \%$ ) [24]. However, microbiologically, it is not easy to identify whether the bacteria detected by the $16 \mathrm{~S}$ rRNA gene sequence alone are pathogenic. Nevertheless, if a number of individuals belong to genera known as pathogenic bacteria or if the frequency of the detection of the nucleotide sequence is high, it is presumed that the possibility of detecting pathogenic bacteria is high. Therefore, the pathogenic bacteria detected by the $16 \mathrm{~S}$ rRNA gene are considered potentially pathogenic bacteria.

The relative abundance of potential pathogens was calculated as the ratio of the number of sequences matched to the pathogen database and the total bacterial sequence. To compare the potential pathogens of carcasses, pig manure and soil samples were chosen because these two samples are representative of a high and basal level of potential pathogens [25]. Triplicate pig manure samples were collected from a pig manure treatment facility in Vietnam. The soil samples were collected from soil for landfill construction in Gyeonggi Province, Korea.

\section{Results}

\subsection{Operational Temperature and Moisture Contents}

During the summer, a relatively high temperature (approximately $40-60^{\circ} \mathrm{C}$ ) was maintained in the bio-agitation experiments (Figure 3). The average moisture content was $11.0 \%$. During the winter, the operational temperature ranged between 10 and $20^{\circ} \mathrm{C}$ (with the exception of the short initial period $\left.\left(30-35{ }^{\circ} \mathrm{C}\right)\right)$, and the average moisture content was $20.5 \%$. 


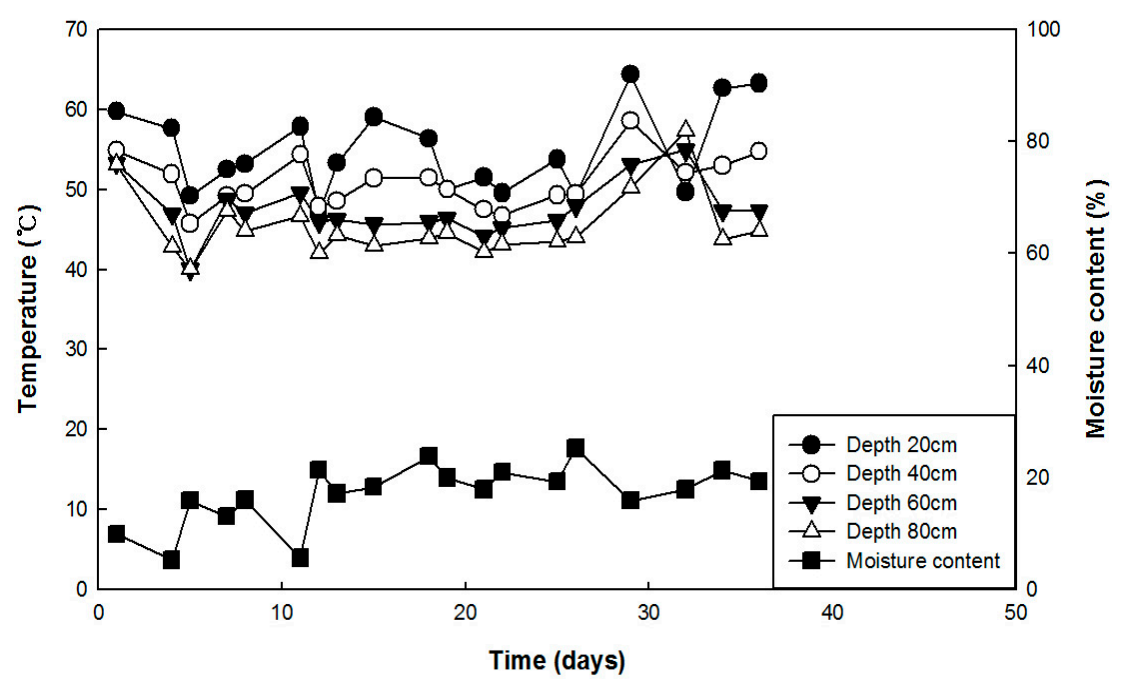

(a)



(b)

Figure 3. Time-course changes in the temperature and moisture contents of the carcasses in the bio-degradation evaluation facility during summer (a) and winter (b).

\subsection{Different Measures for Determining the Degree of Stabilization}

After the carcass-degrading microorganisms were added to the bio-degradation evaluation facility with the bio-agitator, the VS/TS ratio of the carcasses was monitored. As shown in Figure 4, the values ranged from 0.10 to 0.25 , without significant changes. The VS/TS ratios were significantly lower than the VS/TS ratios of the undecomposed carcass bodies (approximately 0.85). This indicates that a significant portion of biomass in the carcass was degraded before the bio-degradation experiments. It was unclear whether the range of VS/TS ratios (0.10-0.25) is representative of finally stabilized carcass products or whether incomplete stabilization occurred during the bio-degradation experiments. Although the average values in Figure $4 \mathrm{~b}$ showed an increasing trend in the VS/TS ratio, it is difficult to conclude that such a trend existed due to the high degree of uncertainty in the VS/TS ratio measurement. 


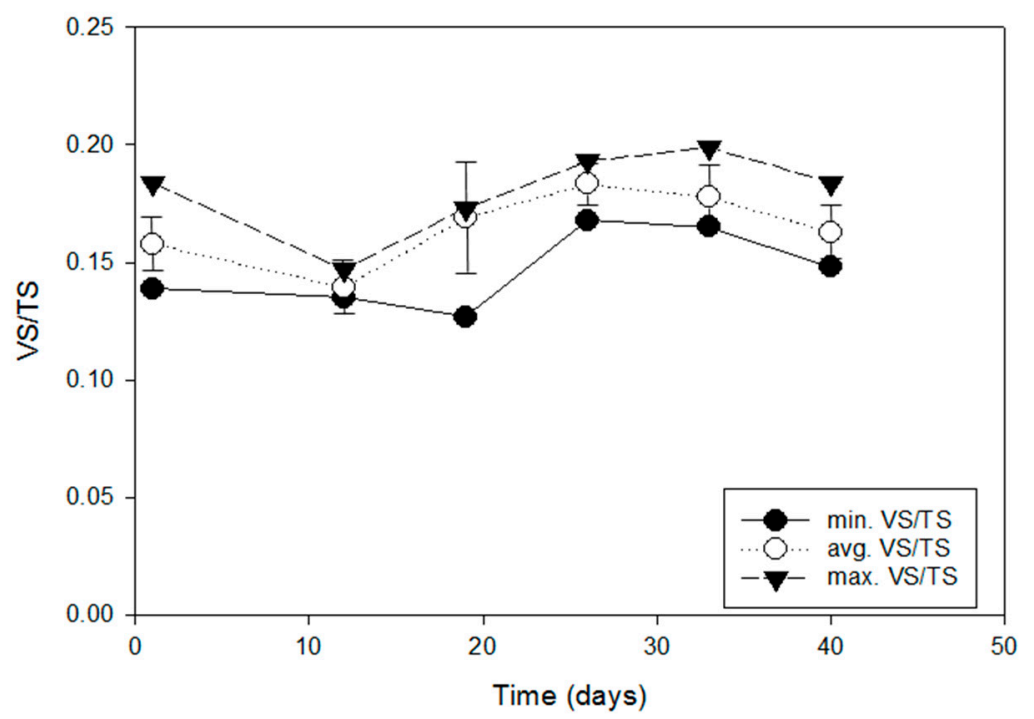

(a)

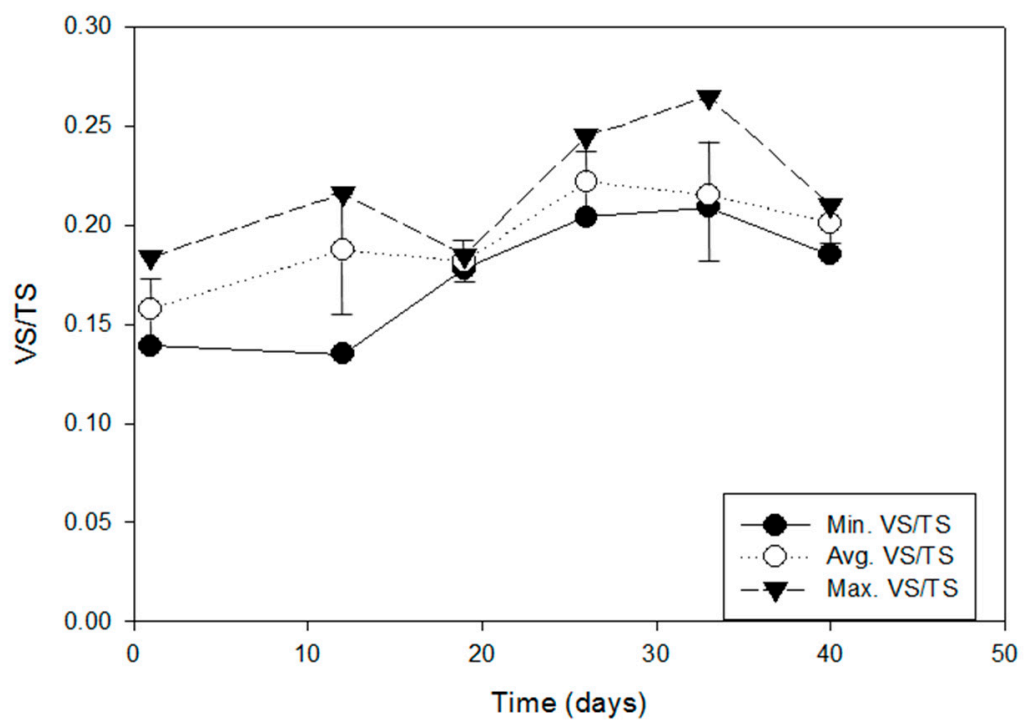

(b)

Figure 4. Maximum, minimum and average values of the volatile solids (VS)/total solids (TS) ratios of the carcasses. Two independent experiments were conducted and are presented in $(\mathbf{a}, \mathbf{b})$.

Because of the limitations of the VS/TS ratio in determining the degree of stabilization, the COD and inorganic nitrogen species were measured to monitor the time-course changes in organic matter and protein degradation of the carcass biomass (Figure 5). The remaining total COD decreased with time from $160,000 \mathrm{mg} / \mathrm{kg}$ to $40,000 \mathrm{mg} / \mathrm{kg}$, indicating that the organic matter in the carcasses was being significantly degraded by the bio-degradation process. In addition, the detection of ammonia indicated the occurrence of protein degradation of the carcass biomass. The total nitrogen $\left(\mathrm{NO}_{2}+\mathrm{NO}_{3}\right.$ $+\mathrm{NH}_{3}$ ) decreased with time from approximately $5000 \mathrm{mg} / \mathrm{kg}$ to $2000 \mathrm{mg} / \mathrm{kg}$, which is consistent with the COD observations. These results indicate that COD and inorganic nitrogen measurements are more effective indicators of stabilization in the bio-degradation process than the VS/TS ratio. 


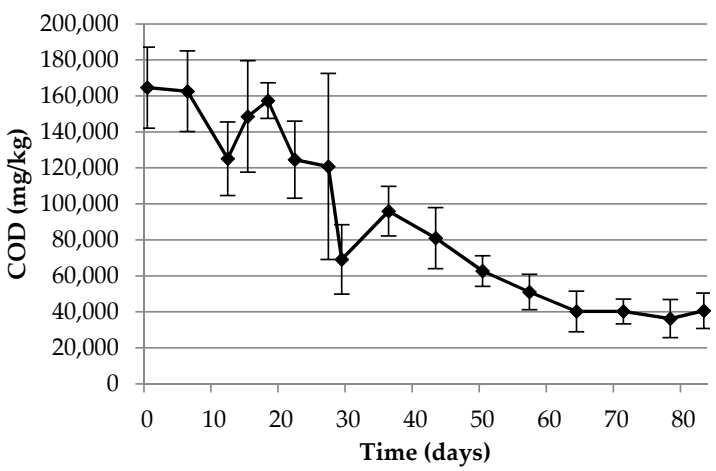

(a)

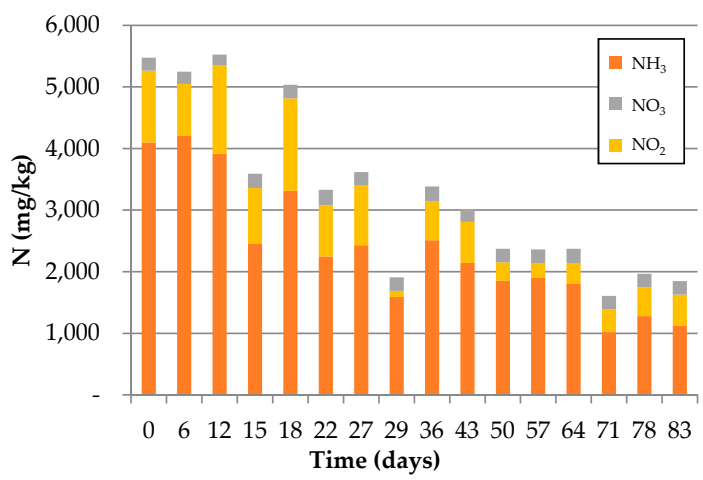

(b)

Figure 5. Time-course changes in the chemical oxygen demand (COD) (a) and inorganic nitrogen pollutants (b).

In the early phase (first week), the germination index was only approximately $20 \%$, which indicated a high degree of toxicity to plants (Figure 6). However, after the second week of applying carcass-degrading microorganisms, the germination indexes were significantly recovered and eventually exceeded $90 \%$ after 10 weeks, indicating minimal toxicity to plant growth. Because the germination index tended to increase with the increasing organic reduction ratio, the enhanced stabilization achieved by applying the carcass-degrading microorganisms may have a positive role in reducing plant toxicity in the products of the bio-degradation process.



Figure 6. Germination index and organic contents during the bio-agitation of carcasses.

\subsection{Detection of Potentially Pathogenic Bacteria}

In the bio-degradation experiments, the total bacterial $16 \mathrm{~S}$ rRNA gene copies and their population diversity were monitored. Even after carcass-degrading microorganisms were added, the total bacterial abundance and diversity did not show significant changes, in contrast to the time-course changes in COD, inorganic nitrogen and organic matter and the germination test (Figure 7). 


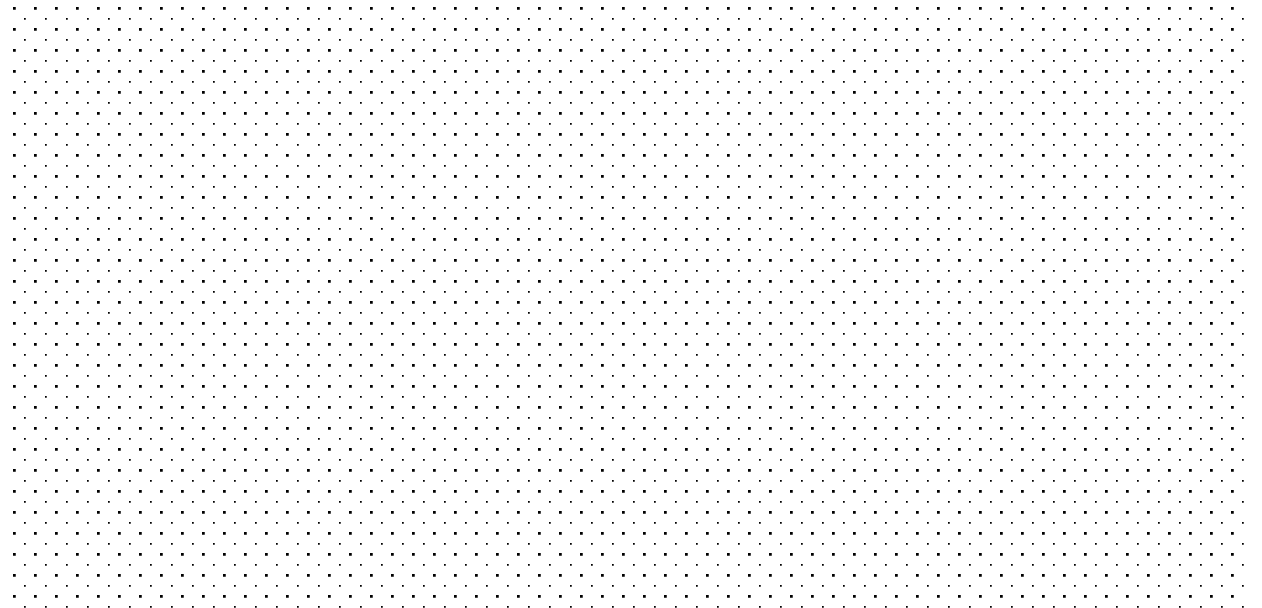

Figure 7. Time-course changes in bacterial diversity and $16 \mathrm{~S}$ rRNA gene copies in the bio-degradation experiments.

However, the relative abundance of potentially pathogenic bacteria significantly decreased after applying carcass-degrading microorganisms (Figure 8). In 2015, the relative abundance of potential pathogens $(6.02 \%)$ of carcasses excavated from the burial site was near that of the highest risk sample (pig manure, 8.13\%). After 60 days of application of carcass-degrading microorganisms, the relative abundance of potential pathogens in the bio-degradation evaluation facility decreased to $2.11 \%$, whereas the relative abundance of potential pathogens of carcasses stored in the pretreatment facility (without the addition of carcass-degrading microorganisms) only decreased to $4.38 \%$. In 2016, the relative abundance of potential pathogens in the pretreatment facility was $2.31 \%$ and eventually approached the level in natural soil $(0.42 \%)$ during bio-degradation treatment for 60 days. The results indicate that the enhanced stabilization achieved by adding carcass-degrading microorganisms resulted in a reduction in microbial hazard detection and the level of microbial risk in the final product from the bio-degradation process is sufficiently low for composting or landfill use.

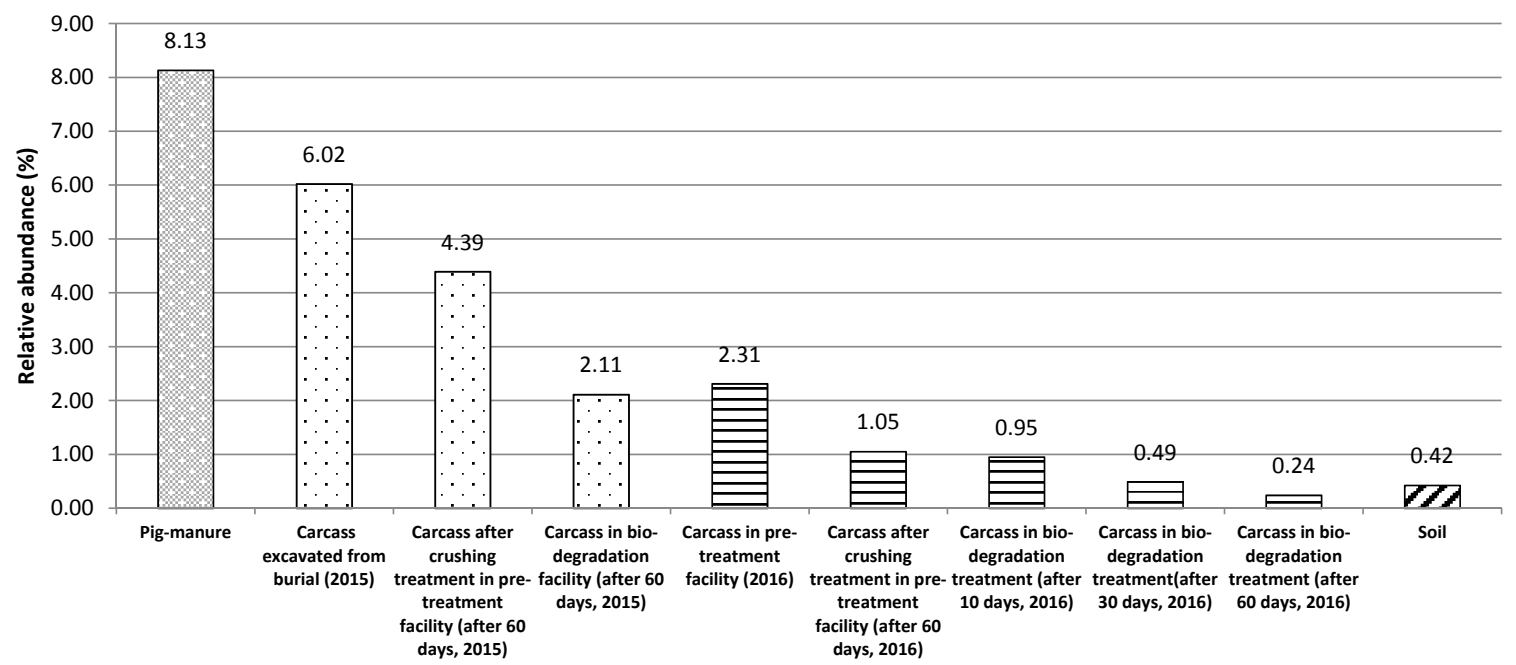

Figure 8. Relative abundance of potentially pathogenic bacteria determined by $16 \mathrm{~S}$ rRNA gene amplicon high-throughput sequencing (via MiSeq).

Although the results of the overall relative abundance of potentially pathogenic bacteria suggest safe use for composting, the possibility of detecting potentially pathogenic bacteria (Clostridium botulinum, Clostridium tetani, and Enterobacter cloacae) represented a health concern for workers at the 
bio-degradation experimental site (Figure 9). Currently, it is unclear whether the quantitative levels of the main potential pathogens in our samples are high from the perspective of workers' health, mainly due to the detection of the pathogenic bacteria based on the $16 \mathrm{~S}$ rRNA gene sequence and the lack of a dose-response relationship between the pathogens and human response. Nevertheless, the hazards of the detected potential pathogens are serious. Clostridium botulinum is regarded as a human pathogen and is an important food spoilage organism associated with dairy, meat, poultry, and fresh and canned fruits and vegetables [26]. Clostridium tetani is the causal agent of tetanus, a disease characterized by muscular spasms that can lead to respiratory failure and, in up to $40 \%$ of cases, death [27].

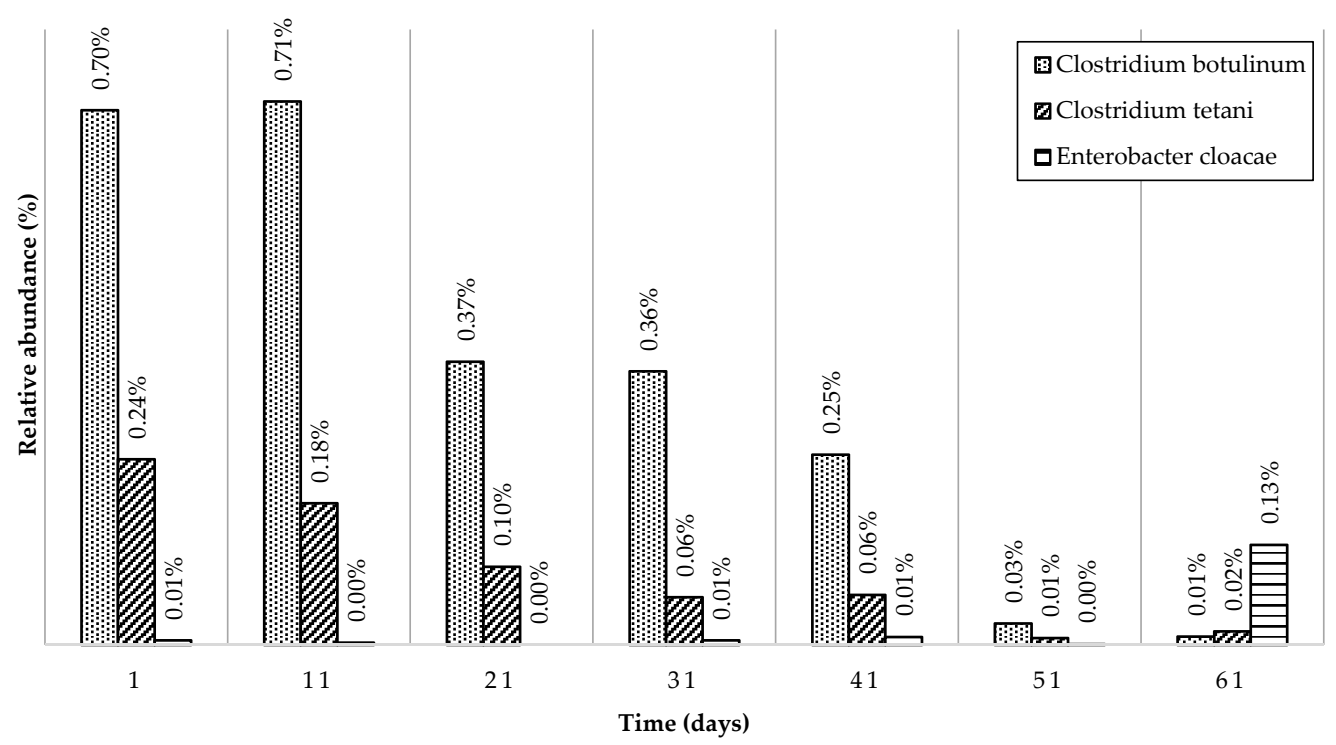

Figure 9. Relative abundance of the main potentially pathogenic bacteria in the bio-degradation experiments.

\section{Discussion}

The feasibility of bio-augmented aerobic composting of excavated carcasses was tested at pilot scale in this work. The results of monitoring COD, organic matter, and nitrogen species showed a significant degree of bio-stabilization of previously buried but undecomposed carcasses although VS measurement was not sufficiently sensitive to detect the same bio-stabilization. The increased germination index of the post-composed product compared to the pre-composted carcasses is evidence of a reduction in plant toxicity by bio-augmented composting. These results demonstrated that the novel burial-composting sequential treatment system was successful in stabilizing carcasses to a suitable level at which the final product from the burial-composting sequential treatment can be used for soil applications, such as farming.

The microbiome monitoring using a NGS method revealed that the bio-augmented aerobic composting effectively reduced microbial risk to human health, as indicated by the decreased relative abundance of potential pathogenic bacteria. The following identification of dominant pathogen candidates showed that the NGS-detected Clostridium botulinum, Clostridium tetani, and Enterobacter cloacae were different from the bacterial pathogen indicators currently used for assessing microbial risk in carcasses in Korea [4]. The findings from the NGS microbiome monitoring provide a basis for improving the accuracy of microbial risk assessment for bio-stabilized product from burial-composting sequential treatment.

If a treatment is urgently required for a large amount of livestock carcasses infected by an epidemic disease, burial seems to be the best option. If sufficient land is available for a long-term burial process, buried carcasses should be kept at the same site(s). However, if a country has a limited land area (as Korea does), burial-composting sequential treatment may be a very economically sound option. 
Although there could be multiple burial sites, a limited number of designated composting sites can handle the bio-stabilization of excavated carcasses from the multiple burial sites. For that case, it is a pre-requirement to guarantee the deactivation of the infection-causing virus before excavating and transferring carcasses.

\section{Conclusions}

In summary, the poorly decomposed carcasses excavated from a burial site after more than three years were treated at a pilot-scale facility by bio-augmented aerobic composting with carcass-degrading microorganisms and mechanical agitation. The measurements of organics and nitrogen compounds, and the NGS detection of potential pathogenic bacteria demonstrated the validity of using the burial-composting sequential treatment system in reducing the risks of groundwater pollution and plant toxicity as well as microbial risk to human health. The findings support the applicability of the final product from the novel burial-composting sequential treatment for farming or/and landfill use(s).

Acknowledgments: This study is supported by the Korean Ministry of Environment as part of the "GAIA Project".

Author Contributions: Seonghoon Kim and Hyeji Kwon conceived and performed the molecular biological experiments; Suchan Park and Haeseong Jeon monitored the data at the facility; Joon-kyu Park contributed to the design of the concept; Joonhong Park was primarily in charge of the paper.

Conflicts of Interest: The authors declare no conflicts of interest.

\section{References}

1. Food and Agriculture Organization. Statistical Pocketbook World Food and Agriculture; Food and Agriculture Organization of the United Nations: Rome, Italy, 2015; p. 30.

2. The World Organisation for Animal Health (OIE). Manual of Diagnostic Tests and Vaccines for Terrestrial Animals 2004. Available online: http:/ /www.oie.int/en/international-standard-setting/terrestrial-manual/ access-online (accessed on 29 December 2016).

3. Ministry of Environment, Korea. Environmental Pollution Management Plan for Animal Carcass Disposal; Ministry of Environment: Sejong, Korea, 2008.

4. Ministry of Environment, Korea. Environmental Guidelines for Animal Carcasss Disposal Sites; Ministry of Environment: Sejong, Korea, 2010.

5. Gwyther, C.L.; Williams, A.P.; Golyshin, P.N.; Edwards-Jones, G.; Jones, D.L. The environmental and biosecurity characteristics of livestock carcass disposal methods: A review. Waste Manag. 2011, 31, 767-778. [CrossRef] [PubMed]

6. Glanville, T.D. Impact of livestock burial on shallow groundwater quality. In Proceedings of the American Society of Agricultural Engineers, Mid Central Meeting ASAE, St. Joseph, MO, USA, 28-29 April 2000.

7. Kim, M.K.; Kim, G. Cost analysis for the carcass burial construction. Soil Groundw. Environ. 2013, 18, 137-147. [CrossRef]

8. Brown, P.; Rau, E.H.; Lemieux, P.; Johnson, B.K.; Bacote, A.E.; Gajdusek, D.C. Infectivity studies of both ash and air emissions from simulated incineration of scrapie-contaminated tissues. Environ. Sci. Technol. 2004, 38, 6155-6160. [CrossRef] [PubMed]

9. Paisley, L.G.; Hostrup-Pedersen, J. A quantitative assessment of the BSE risk associated with fly ash and slag from the incineration of meat-and-bone meal in a gas-fired power plant in Denmark. Prev. Vet. Med. 2005, 68, 263-275. [CrossRef] [PubMed]

10. Kalbasi-Ashtari, A.; Schutz, M.M.; Auvermann, B.W. Carcass rendering systems for farm mortalities: A review. J. Environ. Eng. Sci. 2008, 7, 199-211. [CrossRef]

11. European Commission. The Animal By-Products Regulations (EC) No. 1774/2002; European Commission: Brussels, Belgium, 2002.

12. Kalbasi-Ashtari, A.; Schutz, M.M.; Hawkins, S.E.; Auvermann, B.W. Carcass composting for management of farm mortalities: A review. Compost. Sci. Util. 2008, 13, 180-193. [CrossRef]

13. Glanville, T.D.; Ahn, H.; Akdeniz, N.; Crawford, B.P.; Koziel, J.A. Performance of a plastic-wrapped composting system for biosecure emergency disposal of disease-related swine mortalities. Waste Manag. 2016, 48, 483-491. [CrossRef] [PubMed] 
14. The Board of Audit and Inspection, Korea. Audit Report-Condition of Pollution around Carcass Disposal Sites; The Board of Audit and Inspection: Sejong, Korea, 2015.

15. Dasan Consultants, Korea. 4th Annual Report-Development Safe Circulated Carcass Disposal Formation Technology Considering Improvement of Pollutant Treatment System; Dasan Consultants: Sejong, Korea, 2016.

16. Han, I.; Lee, T.K.; Han, J.; Doan, T.V.; Kim, S.B.; Park, J. Improved detection of microbial risk of releasing genetically modified bacteria in soil by using massive sequencing and antibiotic resistance selection. J. Hazard. Mater. 2012, 227, 172-178. [CrossRef] [PubMed]

17. Kang, M.A.; Kim, M.S.; Choi, B.W.; Son, H.Y. Organic matter analysis and physicochemical properites of leachate from a foot-and-mouth disease landfill site. Korean J. Micro. Biotechnol. 2012, 40, 128-134. [CrossRef]

18. ShShokralla, S.; Spall, J.L; Gibson, J.F.; Hajibabaei, M. Next-generation sequencing technologies for environmental DNA research. Mol. Ecol. 2012, 21, 1784-1805.

19. Choi, H.L.; Richard, L.T. Animal residue and environment: Optimizing the composting process for moisture removal. J. Anim. Sci. Technol. 1997, 39, 446-456.

20. Ritalahti, K.M.; Amos, B.K.; Sung, Y.; Koenigsberg, S.S.; Loffler, F.E. Quantitative PCR targeting 16 rRNA and reductive dehalogenase genes simultaneously monitors multiple Dehalococcoides strains. Appl. Environ. Microbiol. 2006, 72, 2764-2774. [CrossRef] [PubMed]

21. Klindworth, A.; Pruesse, E.; Schweer, T.; Peplies, J.; Quast, C.; Horn, M.; Glockner, F.O. Evaluation of general $16 \mathrm{~S}$ ribosomal RNA gene PCR primers for classical and next-generation sequencing-based diversity studies. Nucleic Acids Res. 2013, 41, e1. [CrossRef]

22. Lane, D.J. Nucleic Acid Techniques in Bacterial Systematics; Stackebrandt, E., Goodfellow, M., Eds.; John Wiley \& Sons: Chishester, UK, 1991; pp. 115-147.

23. Spellerberg, L.F. A tribute to Claude Shannon (1916-2001) and a plea for more rigorous use of species richness, species diversity and the "Shannon-Wiener" index. Glob. Ecol. Biogeogr. 2003, 12, 177-179. [CrossRef]

24. United States Environmental protection Agency. Protocol for Developing Pathogen TMDLs, 1st ed.; United States Environmental protection Agency: Washington, DC, USA, 2001.

25. Bibby, K.; Viau, E.; Peccia, J. Pyrosequencing of the $16 \mathrm{~S}$ rRNA gene to reveal bacterial pathogen diversity in biosolids. Water Res. 2010, 44, 4252-4260. [CrossRef] [PubMed]

26. Guan, T.Y.; Richard, A.H. Pathogen survival in swine manure environments and transmission of human enteric illness-A review. J. Environ. Qual. 2003, 32, 383-392. [CrossRef] [PubMed]

27. Ye, L.; Zhang, T. Pathogenic bacteria in sewage treatment plants as revealed by 454 pyrosequencing. Environ. Sci. Technol. 2011, 45, 7173-7179. [CrossRef] [PubMed] 